\title{
Model Layanan Monitoring Perkembangan Anak
}

\author{
Suryatiningsih ${ }^{1}$ \\ ${ }^{1}$ Fakultas Ilmu Terapan Universitas Telkom \\ Jl Telekomunikasi Terusan Buah Batu Bandung 40257 \\ ${ }^{1}$ suryatiningsih@tass.telkomuniversity.ac.id
}

\begin{abstract}
Abstrak - Aktivitas monitoring merupakan hal yang penting di sebuah daycare. Hal ini dikarenakan adanya kebutuhan untuk memantau aktivitas harian dan perkembangan anak oleh orang tua yang menitipkan anaknya di daycare tersebut. Salah satu bentuk penerapan dari kegiatan monitoring adalah ketersediaan buku komunikasi. Buku komunikasi merupakan sarana untuk mengetahui aktivitas harian anak selama di daycare. Pada buku komunikasi dicatat aktivitas harian dan perkembangan anak. Selain itu, terdapat pencatatan indikator-indikator tertentu untuk beberapa lembaga yang telah menerapkan konsep integrated school and daycare. Indikator tersebut merupakan bentuk pengarahan berdasarkan kurikulum dan silabus yang telah direncanakan. Setiap tahap perkembangan perlu dicatat indikator-indikatornya oleh guru kelas dan biasanya akan dilaporkan dalam bentuk raport/portofolio anak. Berdasarkan pengamatan, raport terbukti kurang efektif untuk melakukan kegiatan monitoring. Hal ini dikarenakan orangtua tidak dapat memantau perkembangan anak setiap saat. Pemakaian raport hanya dilakukan persemester. Pemantauan persemester membutuhkan waktu yang lama. Untuk menyelesaikan hal ini, diperlukan sebuah Content Management System (CMS) yang dapat menyediakan daily report untuk memantau perkembangan anak. Kebutuhan untuk monitoring perkembangan anak oleh orang tua menggunakan CMS berawal dari fakta sedikitnya jumlah aplikasi CMS open source berbasis web yang diimplementasikan untuk manajemen daycare dan preschool. Penyediaan fitur khusus seperti dailyreport, tumbuh kembang anak, dan portofolio (pengganti raport) sangat penting untuk dipantau orang tua kapan pun
\end{abstract}

Kata kunci - daycare, layanan monitoring, perkembangan anak

\begin{abstract}
A daycare needs monitoring activity. This need comes from the requirement of parents who need to monitor the daily activities and development of their children. A communication book is one way to implement monitoring activity. It is to know the children's daily activities during in a daycare. Besides, there are some indicators written in a communication book. These indicators are composed based on the curriculum and syllabus for institution which have implemented the concept of integrated school and daycare. Each stage of development indicators should be noted by the classroom teacher and will be reported in the form of report cards/children's portfolio. Based on observations, report card is less effective which makes the parents cannot monitor the children's development any time, in other words, parental monitoring is only done this semester. It takes 6 months to finish the report book. Content Management System (CMS) for daycare and preschools is needed to make the reporting activities more effective. Parents can control their children using a web-based application by a daily report which generated by the system. Besides, short message service (SMS) can be sent to give parents about school's information. The need for monitoring the development of the children by the parents using a CMS fact originated from the small number of applications of web-based open source CMS implemented for daycare and preschool management. The special features such as daily reports, child development, and portfolio (alternate of report cards) is very important for parents to monitored any time.
\end{abstract}

Keywords - daycare, monitoring service, children's development

\section{PENDAHULUAN}

Daycare merupakan tempat yang tepat dan aman untuk menitipkan anak, saat kedua orangtua pergi bekerja. Terutama dengan pengasuh yang berpengalaman di Dunia Pendidikan Anak. Menurut Perserikatan Bangsa-Bangsa (1990), daycare adalah sarana pengasuhan anak dalam kelompok, biasanya dilaksanakan saat jam kerja danmerupakan upaya terorganisasi untuk mengasuh anak-anak di luar rumah mereka selama beberapa jam dalam satu hari bilamana asuhan orang tua kurang dapat dilaksanakan secara lengkap[4].Beberapa daycare menerapkan konsep integrated school and daycare, dimana pola pengasuhan terintegrasi dengan pembelajaran. Selain diasuh, anak mendapatkan pembelajaran yang diberikan disesuaikan dengan tahapan perkembangan anak. Anak usia dini ada di tahap golden age dalam proses perkembangan seseorang, sehingga sangat penting bagi setiap orangtua dalam memantau perkembangan anak sesuai usianya. Orang tua bekerja tentu sangat membutuhkan keberadaan daycare dan menyadari benar akan pentingnya stimulasi untuk melejitkan kecerdasan di usia dini. Hal ini lah yang melatarbelakangi Almalia dan Luqmanul Hakim untuk membuka kelas Daycare dan Pendidikan Pra Sekolah (Preschool) yang merupakan program untuk anak-anak berusia tiga hingga lima tahun sebelum mereka memasuki Taman Kanak-Kanak[3]. Namun, pada perkembangannya Daycare dan Preschool ini meliputi Pendidikan Anak Usia Dini dari tingkat bayi, 
Kelompok Bermain sampai Taman Kanak-Kanak yang bertempat di daerah kecamatan Bojongsoang Bandung dan sekitarnya. Lokasinya pun tidak jauh dari jalan raya utama, sehingga memudahkan orangtua untuk mobilisasi ke tempat penitipan anak tersebut.

Proses komunikasi antara pihak Daycaredan Preschool untuk pemantauan anak dilakukan melalui buku komunikasi yang di bawa setiap hari oleh anak dan melalui raport yang diserahkan ke orangtua setiap akhir semester. Buku komunikasi berisi kegiatan setiap hari yang dilakukan anak di sekolah.Sedangkan untuk informasi perkembangan anak yang di nilai dari segi motorik, kognitif, bahasa, agama dan kepribadian anak terdapat pada raport yang hanya dapat di cek oleh orangtua di akhir semester. Hal ini kurang efektif, sehingga orangtua tidak dapat memantau perkembangan anak setiap saat, dengan kata lain pemantauan orangtua hanya dilakukan persemester dan ini terlalu lama atau lambat waktunya bagi orangtua. Selain itu penyebaran informasi melalui buku komunikasi dan surat dirasa kurang efektif karena terkadang anak lupa menyampaikan kepada orangtua atau orangtua lupa mengecek buku komunikasi sehingga guru sekolah membantu mengingatkan lewat Short Message Service (SMS) ke setiap orangtua.

Berdasarkan permasalahan di atas dapat dirumuskan dalam rumusan masalah yang lebih sederhana yang diharapkan dapat membantu para orangtua dan guru dalam proses monitoring perkembangan anak, yaitu:

1. Bagaimana memudahkan orangtua melakukan monitoring perkembangan anak yang dapat dilakukan secara berkala dimana saja, kapan saja, tanpa terbatas dengan media buku penghubung dan raport?

2. Bagaimana menyediakan media komunikasi secara umum dan pribadi antara orang tua dan guru, maupun sesama orang tua?

3. Bagaimana menyediakan media untuk broadcast informasi dari sekolah ke orang tua secara realtime?

Dari rumusan masalah yang tertuang di atas, maka ditawarkan sebuah solusi dalam mendukung proses monitoring perkembangan anak dengan mendesain sebuah Sistem Informasi berbasis web yang bisa diakses secara online oleh para orangtua dan guru dalam bentuk berupa Layanan Monitoring Perkembangan Anak yang dapat di kostumisasi kontennya tergantung kebutuhan sekolah yang bersangkutandan memungkinkan para orangtua memantau perkembangan anak secara berkala dan realtime. Selain itu para orangtua dapat berkomunikasi antar sesama orangtua, untuk saling tukar pikiran, saling berdiskusi mengenai perkembangan anak masing-masing. Para orangtua juga dapat berkomunikasi dengan para guru terkait dengan materi pembelajaran yang diberikan dan kemajuan anak dalam berbagai aktivitas stimulasi. Sistem ini memungkinkan setiap guru untuk menilai kemampuan anakberdasarkan indikator pencapaian yang telah ditargetkan oleh sekolah baik dari Muatan Dinas Pendidikan maupun Muatan Yayasan.

Model "Layanan Monitoring Perkembangan Anak" merupakan salah satu strategi yang digunakan, mengingat perkembangan yang sangat pesat dari teknologi saat ini. Layanan yang diberikan berupa sebuah Sistem Informasi berbasis web menggunakan teknologi Content Management Service (CMS) yang dapat diakses oleh pihak Daycare dan Preschool untuk mengkostumisasi indikator perkembangan anak sesuai indikator pada raport dan buku penghubung masing-masing sekolah. Setelah indikator ini didaftarkan oleh pihak Daycare dan Preschool, guru kelas atau administrasi khusus dapat mengisi pencapaian indikator tersebut untuk setiap anak sebagai bentuk pelaporan perkembangan anak di sekolah. Laporan inilah yang nantikan akan menjadi informasi bagi orangtua dalam melakukan monitoring perkembangan anak secara berkala dengan cepat tanpa perlu menunggu akhir semester untuk pembagian raport.

Selain itu pada layanan ini, orangtua akan dapat memonitoring anak di sekolah secara realtime melalui live streaming (terdapat CCTV/IP Camera di setiap Daycare dan Preschool) setiap saat, kapan pun dan dimana pun orangtua berada. Layanan dapat diakses melalui komputer maupun smart phone. Untuk penyebaran informasi dan pengingat event dari pihak Daycare dan Preschool kepada orangtua dapat memanfaatkan layanan broadcast email. Sedangkan untuk media komunikasi antara orangtua dan guru juga antar sesama orangtua dapat memanfaatkan forum dan private message (PM) pada layanan ini.Pemanfaatan layanan ini diharapkan memberikan kontribusi nyata dan memudahkan bagi pihak Daycare dan Preschool serta orangtua dalam melakukan monitoring perkembangan anak secara cepat dan realtime.

\section{METODOLOGI PENELITIAN}

Metodologipenelitian yang digunakan berdasarkan roadmap yang ditampilkan pada gambar 1. Pada roadmap penelitian ini, tahap pertama berupa input yaitu merumuskan permasalahan apa yang dihadapi pada objek penelitian yaitu Daycare dan Preschooluntuk dicarikan solusinya.

Berikutnya masuk ke tahap kedua, yaitu proses melakukan desain sistem untuk menggambarkan model Layanan Monitoring Perkembangan Anak, arsitektur CMS untuk Sistem Monitoring Perkembangan Anak berbasis web, rancangan sistem menggunakan pemodelan berorientasi objek, rancangan abstraksi data dan rancangan antar muka. Selain itu bersamaan dengan tahap kedua ini perlu diidentifikasi sarana dan prasarana pendukung untuk 
desain dan implementasi sistem serta pelatihan kepada pengguna.

Tahap ketiga yaitu pembuatan sistem informasi berupa Layanan Monitoring Perkembangan Anak yang dapat di kostumisasi kontennya sesuai kebutuhan instansi sekolah yang bersangkutan menggunakan arsitektur CMS.

Sistem ini tentunya bertujuan agar dapat memfasilitasi proses monitoring anak oleh orang tua saat berada di Daycare dan Preschool.

Terakhir agar sistem yang diimplementasikan dapat stabil perlu:

1. Melakukan evaluasi mengenai proses monitoring perkembangan anak berdasarkan hasil pelaporan guru sesuai kurikulum pembelajaran masingmasing sekolah oleh pihak sekolah dan orang tua.

2. Melakukan evaluasi terhadap kelancaran komunikasi menggunakan forum, PM dan SMS broadcast.

\section{HASIL DAN PEMBAHASAN}

Objek penelitian Daycare\&Preschool Almalia dan Luqmanul Hakim merupakan suatu wadah yang bergerak dibidang penitipan anak dan pendidikan anak usia dini, yang berpedoman pada pendidikan nasional dan Agama Islam. Akan tetapi pemantauan perkembangan anak yang dilakukan menemui beberapa permasalahan-permasalahan:

1) Permasalahan Buku Komunikasi: Buku Komunikasi adalah media untuk mencatat aktivitas harian anak selama berada di Daycare dan Preschool oleh guru kelas. Apabila terdapat informasi atau catatan penting untuk orangtua, guru akan mencatat di buku komunikasi ini. Kendala yang dihadapi adalah: bagi balita terkadang lupa menyampaikan kepada orangtua, sehingga orangtua harus lebih aktif namun buku komunikasi hanya dapat dilihat malam hari dan orangtua pun bisa saja lupa melakukan pengecekan, selain itu bisa saja buku komunikasi disimpan di sekolah. Hal seperti ini akan menghambat orangtua dalam melakukan monitoring harian dan bisa saja ketinggalan informasi penting.

2) Permasalahan Raport: Raport adalah buku yang berisi keterangan mengenai nilai kepandaian dan prestasi belajar murid di sekolah, yang biasanya dipakai sebagai laporan guru kepada orangtua siswa atau wali murid (Tim Penyusun Kamus Pusat Pembinaan dan Pengembangan Bahasa: 1988). Di Almalia dan Luqmanul Hakim, raport digunakan untuk melaporkan perkembangan anak dari segi motorik, kognitif, bahasa dan indikator lainnya berdasarkan kurikulum sekolah masingmasing. Raport ini dibagikan kepada orangtua di akhir semester. Sehingga orangtua hanya dapat memonitor perkembangan anaknya satu kali persemester, hal ini dirasa kurang efektif dan terlalu lambat. Jadi, belum ada progress yang dapat dimonitor secara berkala oleh orangtua.

3) Permasalahan Komunikasi: Penyebaran informasi dari pihak Daycare dan Preschool saat ini menggunakan surat yang di cetak dan dimasukkan ke dalam buku komunikasi. Apabila ada surat, guru kelas sering memberikan SMS kepada orangtua untuk mengingatkan. Komunikasi orangtua dan guru kelas biasa dilakukan via SMS, begitu juga komunikasi antar sesama orangtua. Dokumentasi kegiatan sekolah pun hanya tersimpan di sekolah, sehingga orangtua harus datang apabila ingin melihatnya. Orangtua kesulitan untuk mengetahui laporan pembayaran biaya bulanan, terutama bagi yang membayar melalui transfer.

4) Permasalahan Teknologi: Tidak semua sekolah memiliki sarana teknologi, seperti komputer, maupun media internet yang dapat digunakan oleh guru untuk melaporkan perkembangan anak kepada orangtua dan juga untuk penyebaran informasi secara broadcast. Pemanfaatan CCTV/IP Camera pun belum digunakan, padahal hal ini sangat penting untuk membantu orangtua memonitoring anak di Daycare secara realtime.

Solusi yang ditawarkan adalah membuat Model "Layanan Monitoring Perkembangan Anak" berbasis web dengan memanfaatkan arsitektur CMS, mengingat perkembangan yang sangat pesat dari teknologi saat ini. Layanan yang diberikan berupa sebuah Sistem Informasi berbasis web yang dapat diakses oleh pihak Daycare dan Preschool untuk mengkostumisasi indikator perkembangan anak sesuai indikator pada raport dan buku penghubung masingmasing sekolah. Setelah indikator ini didaftarkan oleh pihak Daycare dan Preschool, guru kelas atau administrasi khusus dapat mengisi pencapaian indikator tersebut untuk setiap anak sebagai bentuk pelaporan perkembangan anak di sekolah. Laporan inilah yang nantinya akan menjadi informasi bagi orangtua dalam melakukan monitoring perkembangan anak secara berkala dengan cepat tanpa perlu menunggu akhir semester untuk pembagian raport. Tersedianya fasilitas forum dan PM akan memudahkan komunikasi antar pihak sekolah dengan orangtua maupun sesame orangtua. Selain itu fasilitas akses ke CCTV online sangat membantu orangtua dalam mengawasi aktivitas anak selama di daycare.Model Layanan Monitoring Perkembangan Anak pada Daycare dan Preschool yang usulkan dapat dilihat pada Gambar 1. 
Input:

Permasalahan Prioritas yang dihadapi Mitra yang ingin di carikan solusinya

:

1. Bagaimana memudahkan orang tua melakukan monitoring perkembangan anak yang dapat dilakukan dimana saja, kapan saja, tanpa terbatas dengan media buku penghubung dan raport?

2. Belum tersedia media komunikasi secara umum dan pribadi antara orang tua dan guru, maupun sesama orang tua.

3. Belum tersedia media untuk broadcast informasi dari sekolah ke orang tua secara realtime?

Proses (Desain serta Implementasi Sistem Monitoring berbasis Web)

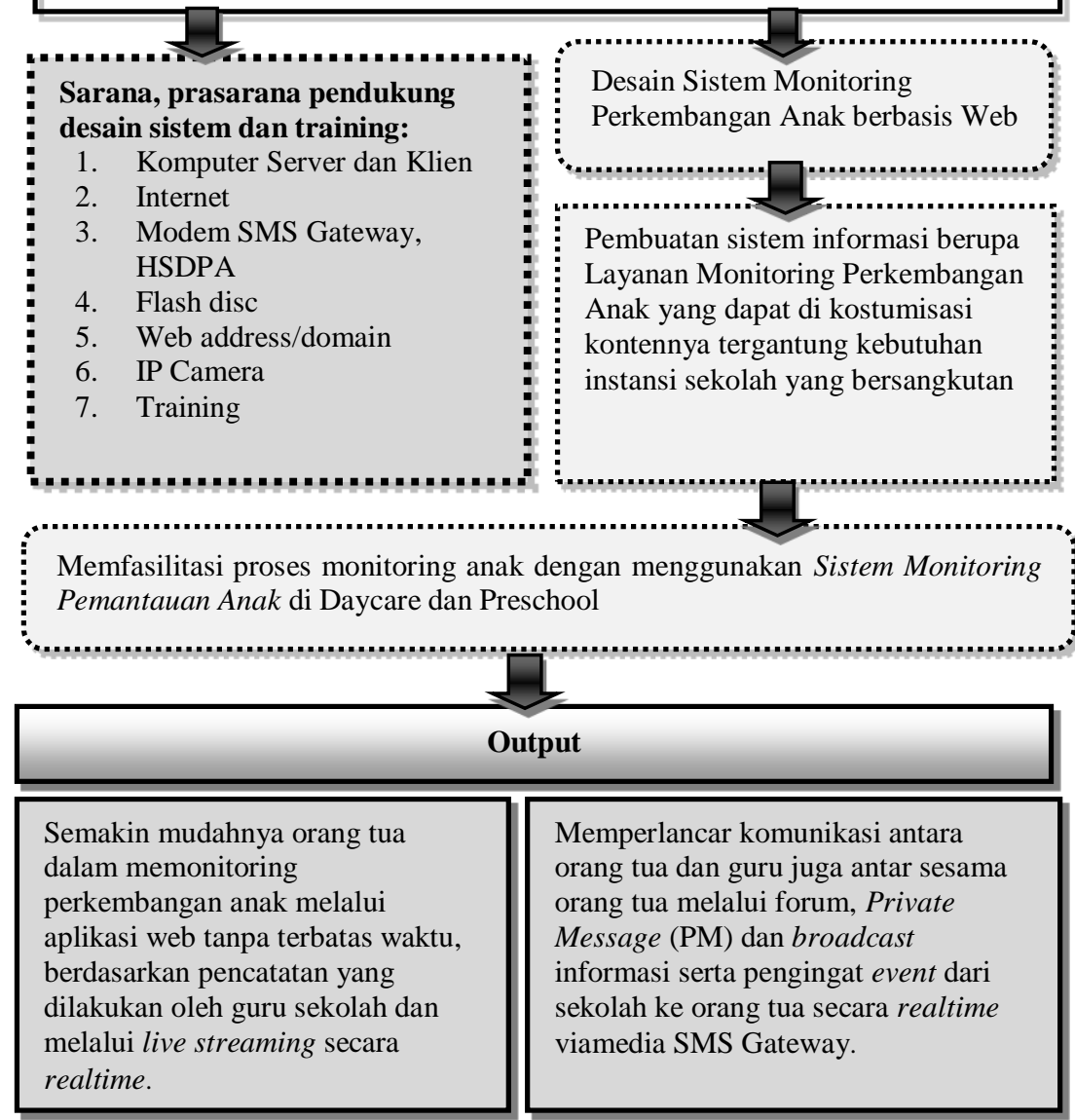

\section{Outcome}

Semakin mudahnya guru, orang tua serta masyarakat dalam mengakses dan memperoleh informasi serta memonitoring perkembangan anak dari awal sampai akhir sekolah, yang dapat dilakukan dimana saja dan kapan saja secara realtime

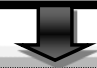

Evaluation

1. Melakukan evaluasi mengenai proses monitoring perkembangan anak berdasarkan hasil pelaporan guru sesuai kurikulum pembelajaran masingmasing sekolah.

2. Melakukan evaluasi terhadap kelancaran komunikasi menggunakan forum, PM dan SMS broadcast.

Gambar 1. Roadmap Metodologi Penelitian 


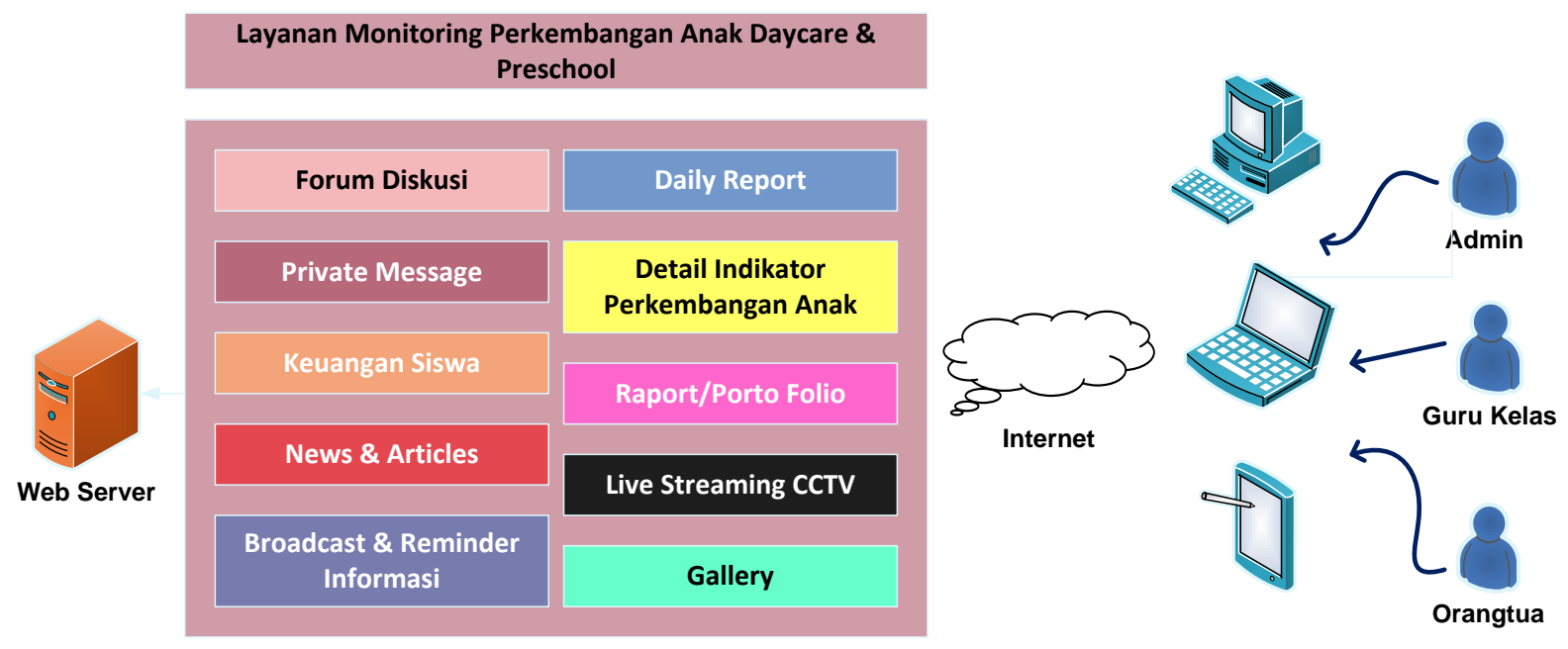

Gambar 2. Model Layanan Monitoring Perkembangan Anak Daycare dan Preschool

Berdasarkan model di atas, terdapat tiga user leveling, antara lain admin, guru kelas dan orangtua. Orangtua memiliki privilege untuk melihat dan berkomentar pada Daily Report, melihat Porto Folio Anak, monitoring anak secara realtime melalui Live Streaming CCTV, melihat Gallery dan keuangan anak, berdiskusi dengan pihak sekolah, mengirim PM kepada guru kelas dan menerima broadcast informasi dari pihak sekolah. Guru kelas memiliki privilege untuk menyimpan riwayat perkembangan anak didik setiap hari sesuai kurikulum dan indikator penilaian pada Raport/Porto Folio melalui layanan Daily Report, mencatat hal-hal yang ingin disampaikan guru kelas kepada orangtua melalui fitur Forum Diskusi dan PM. Sedangkan Admin memiliki privilege untuk mengelola data guru kelas, siswa dan orangtuanya, keuangan siswa, publikasi News \& Articles, broadcast \& reminder informasi, kelola indikator perkembangan anak, mendokumentasikan kegiatan sekolah melalui gallery foto dan akses kepada semua layanan yang dapat diakses oleh guru kelas dan orangtua.

CMS dapat didefinisikan sebagai sebuah aplikasi yang bisa dimanfaatkan untuk mengelola berbagai metode yang berhubungan dengan webpublishing. Menurut Douglas [1], sebuah CMS secara umum bisa dikustomasi dengan menambahkan atau mengurangi fitur yang spesifik, sehingga hanya fitur-fitur tertentu yang diinginkan saja yang akan ditampilkan kepada publik. Dalam perkembangan teknologi saat ini, CMS banyak dikembangkan untuk membuat forum diskusi, website jual beli online, website komunitas, galeri foto online, dan masih banyak lagi.

Fraser [3] menerangkan, CMS setidaknya terdiri daritiga hal, yakni :

- Content Management Application (CMA). CMA akan melakukan manajemen komponen-komponen konten aplikasi, yang terdiri dari gambar, teks, dan sebagainya. Pada CMS yang diusulkan, admin dapat mengelola konten aplikasi sesuai kebutuhan masing-masing sekolah. Setiap sekolah dapat memiliki homepage yang telah dikostumisasi oleh admin.

- Metacontent Management Application (MMA). MMA akan mengatur manajemen informasi yang dimiliki oleh komponen-komponen konten aplikasi.

- Content Delivery Application (CDA). CDA bertugas mengambil komponen-komponen konten, membaca informasi yang dibawa oleh masingmasing komponen tersebut, kemudian menampilkannya kepada pengguna aplikasi.

Berikut ini adalah arsitektur CMS secara umum untuk Sistem Monitoring Perkembangan Anak berbasis web:

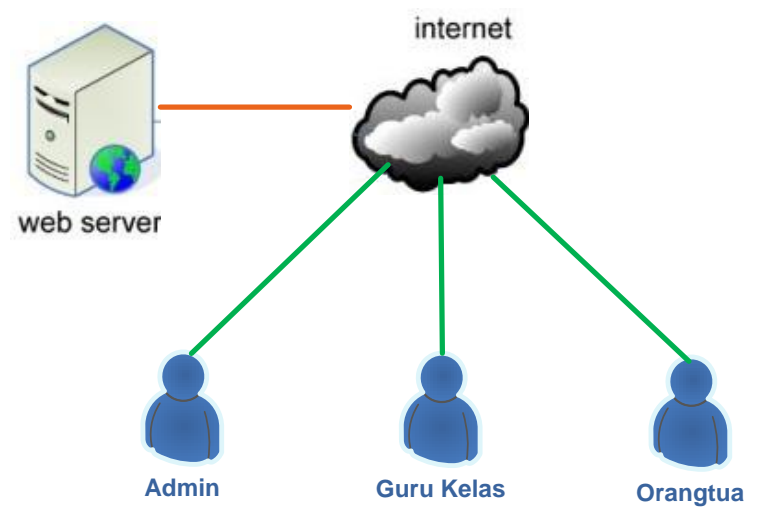

Gambar 3. Arsitektur Sistem Layanan Monitoring Perkembangan Anak Daycare dan Preschool

Dengan arsitektur di atas, seluruh pengguna baik itu admin, guru kelas dan orangtua dapat langsung melakukan pengelolaan dan monitoring perkembangan anak di sekolah. Setiap pengguna akan dapat mengakses sistem menggunakan hak akses masing-masing dan mempunyai akun berupa username dan password. Bagi pihak eksternal yang hanya ingin berselancar di sistem ini, banyak informasi juga yang bisa diperoleh seperti info jenjang sekolah, biaya pendidikan, fasilitas, kegiatan, berita, artikel PAUD dan informasi mengenai pendaftaran calon siswa baru. 


\section{PENUTUP}

Berdasarkan pada hasil penelitian di atas, didapat beberapa kesimpulan dan pekerjaan selanjutnya sebagai berikut:

\section{A. Kesimpulan}

1. Model Layanan Monitoring Perkembangan Anak berbasis web dapat menjadi solusi bagi pihak sekolah dan orangtua untuk menggantikan buku komunikasi, karena di dalam model ini terdapat pengelolaan daily report yang diisikan oleh guru kelas dan dapat diberikan pula catatan oleh orangtua. Selain itu pihak sekolah dapat membuat indikatorindikator perkembangan anak sesuai tahapan usia dan dapat di break down lebih detail lagi sesuai kebutuhan berdasarkan indikator yang terdapat pada buku raport/porto folio siswa. Pihak sekolah dapat menyebarkan informasi kepada orangtua sebagai alternatif surat pemberitahuan, guru kelas dan orangtua dapat saling berkomunikasi melalui forum diskusi dan layanan PM. Pihak sekolah pun menyediakan layanan live streaming CCTV bagi orangtua yang ingin melihat aktivitas buah hatinya.

2. Model yang diusulkan lebih cocok menggunakan arsitektur CMS, karena keuntungan menggunakan arsitektur ini adalah masing-masing sekolah dapat mengkostumisasi fitur-fitur yang akan diaktifkan, menambahkankonten multimedia melalui halaman web, mengganti tema (layout, background image, warna, struktur menu) tanpa perlu menyentuh area pengkodean sistem yang dibangun.

\section{B. Pekerjaan S elanjutnya}

1. Pembuatan desain sistem meliputi rancangan sistem, rancangan antarmuka, rancangan abstraksi data dan struktur tabel nya.

2. Pembuatan sistem informasi berupa Layanan Monitoring Perkembangan Anak yang dapat di kostumisasi kontennya tergantung kebutuhan instansi sekolah yang bersangkutan.

3. Melakukan implementasi pada objek penelitian yaitu Daycare dan Preschool Almalia dan Lukmanul Hakim.

\section{DAFTAR PUSTAKA}

[1] Douglas, Robert T.; Little, Mike; \& Smith,Jared W. 2006.Building OnlineCommunities with Drupal, phpBB, and Wordpress.USA : Apress. 561p

[2] Fraser, Stephen R.G. 2002. Real WorldASP.NET : Building a ContentManagement System. USA : Apress. $405 \mathrm{p}$

[3] Morrison, George S. 2012. Dasar-dasar Pendidikan Anak Usia Dini (PAUD). Jakarta : PT. Indeks

[4] Patmonodewo, DR. Soemiati. 2003. Pendidikan Anak Sekolah. Jakarta : Rineka Cipta. 